\title{
Distribution and bacterial availability of dissolved neutral sugars in the South East Pacific
}

\author{
R. Sempéré, M. Tedetti, C. Panagiotopoulos, B. Charrière, and F. Van Wambeke \\ Laboratoire de Microbiologie, Géochimie et Ecologie Marines (LMGEM), UMR 6117, CNRS, Université de la Méditerranée, \\ Centre d'Océanologie de Marseille, Campus de Luminy, Case 901, 13288 Marseille Cedex 9, France
}

Received: 3 December 2007 - Published in Biogeosciences Discuss.: 14 February 2008

Revised: 23 April 2008 - Accepted: 18 July 2008 - Published: 25 August 2008

\begin{abstract}
The distribution and bacterial availability of dissolved neutral sugars were studied in the South East Pacific from October to December 2004 during the BIOSOPE cruise. Four contrasting stations were investigated: Marquesas Islands (MAR), the hyper-oligotrophic South Pacific Gyre (GYR), the eastern part of the Gyre (EGY), and the coastal waters associated to the upwelling area off Chile (UPW). Total (free and combined) dissolved neutral sugar (TDNS) concentrations were in the same order of magnitude at MAR $(387 \pm 293 \mathrm{nM})$, GYR $(206 \pm 107 \mathrm{nM})$, EGY $(269 \pm 175 \mathrm{nM})$, and UPW $(231 \pm 73 \mathrm{nM})$, with the highest and lowest concentrations found at MAR $(30 \mathrm{~m}, 890 \mathrm{nM})$ and EGY $(250 \mathrm{~m}, 58 \mathrm{nM})$, respectively. Their contribution to dissolved organic carbon (TDNS-C $\times \mathrm{DOC}^{-1} \%$ ) was generally low for all sites varying from $0.4 \%$ to $6.7 \%$ indicating that South East Pacific surface waters were relatively poor in neutral sugars. Free dissolved neutral sugar (FDNS; e.g. sugars analyzed without hydrolysis) concentrations were very low within the detection limit of our method $(5-10 \mathrm{nM})$ accounting for $<5 \%$ of the TDNS. In general, the predominant sugars within the TDNS pool were glucose, xylose, arabinose, and galactose, while in the FDNS pool only glucose was present. TDNS stock to bacterial production ratios (integrated values from the surface to the deep chlorophyll maximum) were high at GYR with respect to the low primary production, whereas the opposite trend was observed in the highly productive area of UPW. Intermediate situations were observed for MAR and EGY. Bioavailability of dissolved organic matter (DOM) exposed to natural solar radiation was also experimentally studied and compared to dark treatments. Our results showed no or little detectable effect of sunlight on DOM bacterial assimilation in surface waters of UPW and GYR, while a significant stimulation was found in MAR and
\end{abstract}

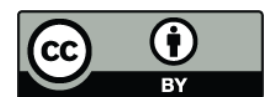

Correspondence to: R. Sempéré (richard.sempere@univmed.fr)
EGY. The overall results clearly suggest that DOM is less labile at GYR compared to UPW, which is consistent with the observed accumulation of dissolved organic carbon and the elevated C/N ratios reported by Raimbault et al. (2008).

\section{Introduction}

Sugars are among the most abundant components in seawater constituting structural and storage compounds (Painter, 1983; Parsons et al., 1984; Benner and Kaiser, 2003) of marine organisms and generally account $20-40$ dry wt. \% of plankton, 17 dry wt. \% of bacteria (Stouthamer, 1977), 2$30 \%$ of dissolved organic matter (DOM; Pakulski and Benner, 1994; Benner, 2002), and 50-70\% of the high molecular weight DOM (>1 kDa; Benner et al., 1992; Aluwihare et al., 1997). Two major categories of sugars have been identified in DOM: Monosaccharides (free monomers) and polysaccharides (neutral sugars released after acid hydrolysis). Concentrations of free sugars have been found extremely low $(<50 \mathrm{nM})$ compared to the dissolved polysaccharides (200$800 \mathrm{nM}$ ) (Benner, 2002 and references therein). Of the free sugars glucose appears to be quantitatively most important although arabinose and fructose have also been detected (Rich et al., 1996, 1997; Skoog et al., 1999; Kirchman et al., 2001). Only few vertical profiles of dissolved sugars in seawater have been already published (Skoog and Benner, 1997; Amon and Benner, 2003) and there is a limited number of studies dealing with the bacterial reactivity of polysaccharides and monosaccharides (free glucose) in the water column for different trophic regimes (Rich et al., 1996; Skoog et al., 1999; Kirchman et al., 2001).

The South East Pacific waters encompass a wide range of primary productivity ranging from the most oligotrophic and clearest waters of the world ocean in the central part of the South Pacific Gyre (SPG) (Claustre and Maritorena, 2003; Morel et al., 2007; Tedetti et al., 2007) to the highly eutrophic

Published by Copernicus Publications on behalf of the European Geosciences Union. 


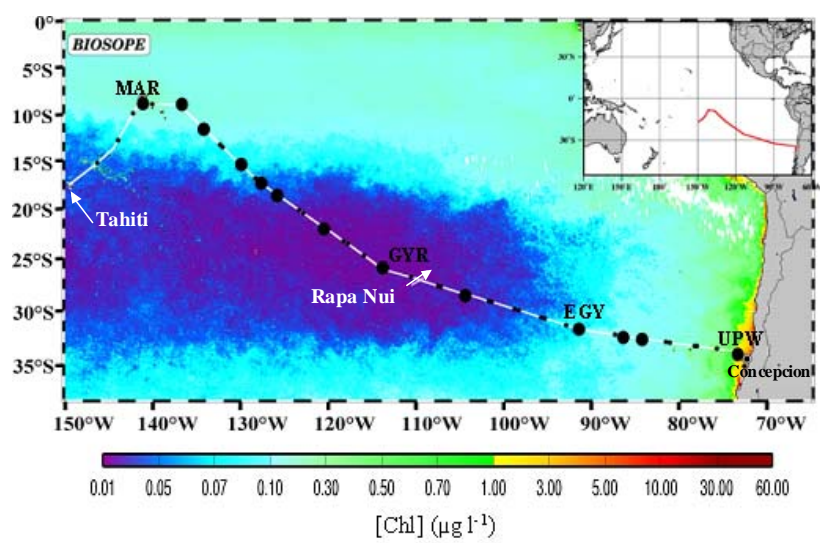

Fig. 1. Map of the BIOSOPE cruise track superimposed on a Sea-viewing Wide Field-of-view Sensor (SeaWiFS) composite for November and December showing the chlorophyll concentration in the upper layer. The long (3-6 days) stations studied for dissolved neutral sugar content, bacterial production, DOM-photodegradation and -biodegradation experiments are Marquesas Islands (MAR), center of the South Pacific Gyre (GYR), East of the South Pacific Gyre (EGY) and upwelling off Chile (UPW). Rapa Nui is Easter Island. http://www.obs-vlfr.fr/proof/vt/op/ec/biosope/bio.htm.

upwelling area off Chile (Carr, 2002). However, very little is known about DOM dynamics in the South Pacific and there is no report dealing with sugar distribution in the SPG. Such a study could help to evaluate DOM characteristics in terms of bacterial cycling and abiotic degradation (solar radiation).

This paper aims to provide data on the molecular distribution of sugars in the DOM pool in the South East Pacific waters at four contrasting stations and to understand its photochemical and bacterial reactivity.

\section{Material and methods}

\subsection{Sampling}

Sampling was performed along a $8000 \mathrm{~km}$ transect in the South East Pacific during the BIogeochemistry and Optics SOuth Pacific Experiment (BIOSOPE) cruise (24 October11 December 2004). To study the molecular distribution and bacterial availability of dissolved neutral sugars, we collected

1. depth profile samples $(0-500 \mathrm{~m})$ and

2. large volume samples (201) for DOM-photodegradation and -biodegradation experiments.

Four stations were sampled: Marquesas Islands (MAR), center of the SPG (GYR), East of the SPG (EGY), and the upwelling of Chile (UPW) (Fig. 1; Table 1). Biogeochemical and physical characteristics of these sampling sites are described in detail elsewhere (Claustre et al., 2008). Surface and underwater solar irradiance measurements were also performed at these stations.

Discrete seawater samples were taken with 121 Niskin bottles mounted on a CTD/rosette and washed with $1 \mathrm{M} \mathrm{HCl}$ and Milli-Q water before the cruise. Rubber made ribbons and o-rings of the original Niskin bottles were replaced with silicon ribbons and Viton o-rings, respectively. Samples for dissolved sugar and bacterial production (BP) measurement were collected at six depths (maximum depth sampled: $160 \mathrm{~m}$ in MAR, $270 \mathrm{~m}$ in GYR, $250 \mathrm{~m}$ in EGY, and $500 \mathrm{~m}$ in UPW) close to solar noon (bio-optical CTD cast) directly (without tubing) from the Niskin bottles into precombusted $\left(450^{\circ} \mathrm{C}, 6 \mathrm{~h}\right) 500$-ml glass bottles, first or after gas sampling to avoid organic carbon contamination. The bottles were rinsed two times with the respective water samples before filling. Following collection, seawater for dissolved sugar analysis was filtered through $0.2-\mu \mathrm{m}$ polycarbonate filters (Nuclepore, $47 \mathrm{~mm}$ filter diameter) which were washed with a few $\mathrm{ml}$ of $1 \mathrm{M} \mathrm{HCl}, 21$ of Milli-Q water, and $150 \mathrm{ml}$ of sample prior to filtration. Samples were transferred to $5 \mathrm{ml}$ polypropylene tubes (prewashed with $1 \mathrm{M} \mathrm{HCl}$ and Milli-Q water) and stored in the dark at $-18^{\circ} \mathrm{C}$. BP measurements were made on unfiltered seawater. For DOMphotodegradation and -biodegradation experiments, samples were collected at two depths ( $5 \mathrm{~m}$ and deep chlorophyll maximum (DCM), except in MAR: 5 and $160 \mathrm{~m}$ ) at midnight in 201 Nalgene carboy bottles using Teflon tubing. Samples were immediately processed in a temperature controlled laboratory on board. Plastic gloves were worn and care was taken to minimize contamination during sampling and the following procedure. Glassware filtration material was precombusted before the cruise and rinsed with $1 \mathrm{MHCl}$ and Milli-Q water after each sample. Sampling information is summarized in Table 1.

\subsection{DOM-photodegradation and -biodegradation experi- ments}

After sampling, seawater was filtered through precombusted GF/F filters (Whatman, diameter: $142 \mathrm{~mm}$ ) using a peristaltic pump with acid-cleaned silicon tubing and then through acid-cleaned Whatman POLYCAP AS $0.2 \mu \mathrm{m}\left(820-\mathrm{cm}^{2}\right)$ filter capsules to exclude bacteria and others microorganisms. Seawater was also filtered under a low vacuum $(<50 \mathrm{~mm} \mathrm{Hg})$ through $0.8 \mu \mathrm{m}$ polycarbonate filters (Nuclepore, diameter: $47 \mathrm{~mm}$ ) to prepare the bacterial inoculum whilst excluding predators. The filters were washed with $150 \mathrm{ml}$ of $1 \mathrm{M} \mathrm{HCl}$ (filter capsule and Nuclepore), 21 of Milli-Q water and 1501 of sample (filter capsule, Nuclepore and GF/F) prior to filtration. The $0.2 \mu \mathrm{m}$ filtered seawater (here after called DOMsolution) was distributed into precombusted 51 glass bottles and stored at $4^{\circ} \mathrm{C}$ in the dark until morning. DOM-solutions were transferred into $100 \mathrm{ml}$ quartz and Pyrex Winkler flasks and exposed on the ship deck for one day $(\sim 8 \mathrm{~h}$ around solar noon) to natural solar radiation in a recirculating water 
Table 1. Site location, date of sampling, deep chlorophyll maximum (DCM), depth of the euphotic zone ( $Z_{e}, 1 \%$ surface PAR), bacterial and primary productions integrated down to DCM (I-BP and I-PP) after Van Wambeke et al. (2008a) at the four stations in the South East Pacific. For depths sampled for DOM-photodegradation and biodegradation experiments, temperature (T), salinity (SAL), total chlorophyll$a$ (TChl- $a$ ) concentration after Ras et al. (2008), bacterial abundance (BA) and leucine incorporation rates (LEU) are also indicated. The maximum depths were $3623 \mathrm{~m}, 3013 \mathrm{~m}, 3393 \mathrm{~m}$ and $4825 \mathrm{~m}$ for MAR, GYR, EGY, and UPW sampling stations, respectively.

\begin{tabular}{|c|c|c|c|c|c|c|c|c|c|c|c|c|}
\hline Site & Latitude & Longitude & Date & $Z_{e}$ & I-BP & I-PP & depth & $T$ & SAL & TChl- $a$ & $\mathrm{BA}$ & LEU \\
\hline & & & & $\mathrm{m}$ & $\mathrm{mgCm}^{-2} \mathrm{~d}^{-1}$ & $\mathrm{mgCm} \mathrm{m}^{-2} \mathrm{~d}^{-1}$ & $\mathrm{~m}$ & ${ }^{\circ} \mathrm{C}$ & & $\mu \mathrm{gl}^{-1}$ & $\mathrm{x} 10^{5} \mathrm{ml}^{-1}$ & $\mathrm{pmoll}^{-1} \mathrm{~h}^{-1}$ \\
\hline \multirow[t]{3}{*}{ MAR* } & $08^{\circ} 21^{\prime} \mathrm{S}$ & $141^{\circ} 16^{\prime} \mathrm{W}$ & $27^{\mathrm{a}}, 28^{\mathrm{b}}, 29^{\mathrm{c}}$ Oct. & 70 & 144 & 683 & $5 \mathrm{~m}$ & 27.9 & 35.55 & 0.27 & 8.25 & 44.0 \\
\hline & & & & & & & $\operatorname{DCM}(60 \mathrm{~m})$ & 27.7 & 35.55 & 0.38 & 9.17 & 29.4 \\
\hline & & & & & & & $160 \mathrm{~m}^{*}$ & 22.4 & 35.99 & 0.018 & 2.55 & 2.3 \\
\hline \multirow[t]{2}{*}{ GYR } & $26^{\circ} 03^{\prime} \mathrm{S}$ & $114^{\circ} 00^{\prime} \mathrm{W}$ & $12^{\mathrm{b}}, 14^{\mathrm{a}}, 15^{\mathrm{c}}$ Nov. & 160 & 50 & 159 & $5 \mathrm{~m}$ & 22.6 & 36.01 & 0.019 & 3.36 & 8.2 \\
\hline & & & & & & & $\operatorname{DCM}(175 \mathrm{~m})$ & 19.05 & 35.51 & 0.18 & 3.12 & 6.6 \\
\hline \multirow[t]{2}{*}{ EGY } & $31^{\circ} 50^{\prime} \mathrm{S}$ & $091^{\circ} 27^{\prime} \mathrm{W}$ & $26^{\mathrm{b}}, 28^{\mathrm{a}, \mathrm{c}}$ Nov. & 88 & 55 & 196 & $5 \mathrm{~m}$ & 18.1 & 34.69 & 0.064 & 8.68 & 13.2 \\
\hline & & & & & & & $\operatorname{DCM}(80 \mathrm{~m})$ & 16.1 & 34.61 & 0.23 & 3.95 & 14.7 \\
\hline \multirow[t]{2}{*}{ UPW } & $34^{\circ} 01^{\prime} \mathrm{S}$ & $073^{\circ} 21^{\prime} \mathrm{W}$ & $06^{\mathrm{a}, \mathrm{c}}, 07^{\mathrm{b}}$ Dec. & 34 & 226 & 4362 & $5 \mathrm{~m}$ & 15.7 & 34.24 & 1.46 & 12.5 & 226 \\
\hline & & & & & & & DCM $(40 \mathrm{~m})$ & 13.3 & 34.31 & 3.06 & 12.7 & 396 \\
\hline
\end{tabular}

* $160 \mathrm{~m}$, is the depth of the second DOM-photodegradation and -biodegradation experiment at MAR site

a Sampling for $T$, SAL, dissolved neutral sugar, BA and LEU profiles (bio-optical CTD cast, close to solar noon)

b Sampling for DOM-photodegradation and -biodegradation experiments (0:00 CTD cast). Surface solar irradiance was measured continuously during the exposure period $(\sim 8 \mathrm{~h}$ around solar noon $)$

c Underwater solar irradiance measurements (close to solar noon)

bath $(0.1 \mathrm{~m}$ depth). Surface water temperatures ranged from $16^{\circ} \mathrm{C}$ (UPW) to $28^{\circ} \mathrm{C}$ (MAR) (Table 1). Samples were irradiated in duplicates for two light conditions: so-called "Full Sun" (FS: total solar radiation in quartz flasks) and "Dark" (Pyrex flasks wrapped with aluminum foil). Before and immediately after irradiation of DOM-solutions, aliquots were taken in FS and Dark samples for free dissolved neutral sugar (FDNS) measurements and stored in $5 \mathrm{ml}$ polypropylene tubes (prewashed with $1 \mathrm{M} \mathrm{HCl}$ and Milli-Q water) in the dark at $-18^{\circ} \mathrm{C}$. During DOM-photodegradation, the bacterial inoculum was kept in the dark at in situ temperature. Quartz and Pyrex flasks were precombusted before the cruise and extensively washed with $1 \mathrm{M} \mathrm{HCl}$ and Milli-Q water between different sets of samples during the cruise.

Bacterial response to the DOM changes after photodegradation was quantified through biodegradation experiments. After irradiation, the DOM-solutions were mixed with the (unirradiated) bacterial inocula (1/6, inoculum/DOMsolution final ratio) and then dispensed in duplicate into several precombusted 100-ml Pyrex Winkler flasks and incubated in the dark at in situ temperature. No nutrients were added in the mixed solutions in order to measure the response of bacteria under "natural" conditions. Subsamples were taken and analyzed for BP at time $0,24,48$, and $72 \mathrm{~h}$ of incubation. For each experiment, killed controls were made by addition of $\mathrm{HgCl}_{2}$ (final concentration: $10 \mathrm{mgl}^{-1}$ ), incubated with other samples and analyzed at the end of the experiment for $\mathrm{BP}$.

\subsection{Total dissolved neutral sugars (TDNS)}

After a quick defrosting, samples $(4 \mathrm{ml})$ for total (free and combined) dissolved neutral sugar (TDNS) analysis were transferred into precombusted Pyrex vials and hydrolyzed under $\mathrm{N}_{2}$ with $0.1 \mathrm{M} \mathrm{HCl}$ at $100^{\circ} \mathrm{C}$ for $20 \mathrm{~h}$ (Burney and Sieburth, 1977). After hydrolysis, samples were not neutralized (to avoid contaminations from the addition of calcium carbonate) but directly desalted using AG2-X8 and AG50W-X8 Bio-Rad ion exchange resins according to Mopper et al. (1992). The reactions between resins and acidified samples $(\mathrm{pH} \mathrm{1})$ favored the elimination of carbonates (which were released into the sample by anionic exchange with chloride) into $\mathrm{CO}_{2}$, allowing a partial neutralization of sugar samples ( $\mathrm{pH}$ 3-4.5 after desalting). A portion of the initial sample was also directly desalted (see above) without hydrolysis in order to estimate the amount of FDNS.

The samples were injected into a WATERS-HPLC system through a manual Rheodyne valve equipped with a $200 \mu \mathrm{l}$ sample loop. The mobile phase consisted of a mixture 95/5 (v/v) of low-carbonate $\mathrm{NaOH}(20 \mathrm{mM}$, Baker) and Milli-Q water which was pumped at a flow rate of $0.7 \mathrm{ml} \mathrm{min}^{-1}$ on isocratic mode. Neutral sugars were separated on a Dionex Carbopac PA-1 anion exchange column $(4 \times 250 \mathrm{~mm})$ with $19 \mathrm{mM} \mathrm{NaOH}$ at $17^{\circ} \mathrm{C}$ (column temperature) and were detected by a Decade electrochemical detector (Antec Leyden BV) using a gold working electrode and a Pd reference electrode (Panagiotopoulos et al., 2001; Panagiotopoulos and Sempéré, 2005). A $1 \mathrm{MNaOH}$ solution was added to the eluent stream by a post-column pump at a flow rate of $0.2 \mathrm{ml} \mathrm{min}^{-1}$ to increase detector sensitivity. To avoid 
Table 2. $10 \%$ irradiance depths $\left(Z_{10 \%}\right)$ in the UVB $(305 \mathrm{~nm})$, UVA $(325,340,380 \mathrm{~nm})$ and visible $(412,443,490,565 \mathrm{~nm})$ spectral domains at the four stations in the South East Pacific.

\begin{tabular}{lllllllll}
\hline \multicolumn{7}{c}{$Z_{10 \%}(\mathrm{~m})$} \\
\hline Site & $305 \mathrm{~nm}$ & $325 \mathrm{~nm}$ & $340 \mathrm{~nm}$ & $380 \mathrm{~nm}$ & $412 \mathrm{~nm}$ & $443 \mathrm{~nm}$ & $490 \mathrm{~nm}$ & $565 \mathrm{~nm}$ \\
MAR & 9.6 & 17.1 & 23.3 & 37.0 & 39.2 & 41.9 & 49.2 & 26.8 \\
GYR & 21.4 & 40.4 & 57.4 & 108.9 & 107.0 & 113.1 & 97.4 & 36.5 \\
EGY & 11.8 & 22.7 & 28.3 & 53.4 & 47.1 & 49.0 & 54.4 & 27.4 \\
UPW & 3.0 & 4.9 & 5.8 & 8.8 & 9.9 & 10.6 & 14.5 & 17.8 \\
\hline
\end{tabular}

absorption of carbonates by $\mathrm{NaOH}$, eluent solutions were degassed before use and constantly purged with helium at a flow rate of $4 \mathrm{ml} \mathrm{min}^{-1}$.

Recoveries of desalting, estimated in spiked $(20-100 \mathrm{nM})$ sodium chloride solutions ranged from 72 to $80 \%$ for fucose, rhamnose, arabinose, mannose, xylose and ribose, and between $85-100 \%$ for galactose and glucose, respectively. Procedural blanks run with desalted sodium chloride solutions, showed only small peak of glucose $(\sim 5 \mathrm{nM})$, even though a systematic peak induced by desalting was coeluted with fructose avoiding its quantification. The detection limit was 5$10 \mathrm{nM}$ for all sugars. Analytical errors determined from duplicate analysis were $<8 \%$ for all sugars except ribose $(15 \%)$. Concentrations of dissolved sugars presented in this study are corrected for the blank values (glucose).

\subsection{Bacterial production (BP)}

BP was estimated from the incorporation rate of ${ }^{3} \mathrm{H}$-leucine into proteins using the centrifugation method (Smith and Azam, 1992). The detailed protocol is fully described in Van Wambeke et al. (2008a). Briefly, $1.5 \mathrm{ml}$ duplicate samples were incubated in the dark for $1-2 \mathrm{~h}$ with $20 \mathrm{nM}$ addition of leucine. The experimental error was calculated as half the difference between two duplicates and averaged $6 \%$ of BP rates. The leucine-carbon conversion factor used was $1.5 \mathrm{~kg} \mathrm{C}$ per mole leucine incorporated.

\subsection{Surface and underwater solar irradiance}

Two profiles of downward irradiance were made at each station (Fig. 1) close to solar noon using a Satlantic MicroPro free-fall profiler equipped with OCR-504 downward irradiance in the UVB $(305 \mathrm{~nm})$, UVA $(325,340$ and $380 \mathrm{~nm})$, and visible (412, 443, 490 and $565 \mathrm{~nm}$ ) spectral domains. Surface irradiance was simultaneously measured at the same channels on the ship deck using other OCR-504 irradiance sensors to account for the variations of cloud conditions during the cast, as well as to monitor UV and visible irradiances during the exposure period for the DOM-photodegradation experiments. A detailed description of optical measurements and determination of $10 \%$ irradiance depth $\left(Z_{10 \%}\right.$ in $\left.\mathrm{m}\right)$ is given elsewhere (Tedetti et al., 2007).

\subsection{Statistical analyses}

The Mann-Whitney test was used to evaluate the differences between biogeochemical parameters among the four sites, as well as to compare leucine incorporation rates between dark and full sun treatments in the DOM-photodegradation and biodegradation experiments. The significance threshold was set at $p<0.05$.

\section{Results and discussion}

\subsection{General observations}

The main biogeochemical characteristics of the four stations are presented in Table 1. DCM ranged from $40 \mathrm{~m}$ (UPW) to $175 \mathrm{~m}$ (GYR) and was very close to the corresponding depth of euphotic zone $\left[Z_{e u}\right.$, the depth of $1 \%$ surface photosynthetically available radiation (PAR)]. Total Chlorophyll- $a$ (TChla) concentrations within subsurface and DCM depths as well as $\mathrm{BP}$ and primary production (PP) values integrated to DCM (I-BP and I-PP) showed large variations between the stations (Table 1). At the GYR station, TChl- $a$, I-BP, and I-PP values were low compared to the other stations, which further confirm its hyper-oligotrophic status. In this area, PP was strongly nutrient-limited because of the absence of terrestrial inputs and because of the depth of nutricline $(0.01 \mu \mathrm{M} \mathrm{N}$ at $\sim 160 \mathrm{~m}$; Raimbault et al., 2008). At the MAR station, TChl$a\left(0.27\right.$ and $0.38 \mu \mathrm{g} \mathrm{l}^{-1}$ for $5 \mathrm{~m}$ and $60 \mathrm{~m}$, respectively), and I-PP $\left(683 \mathrm{mg} \mathrm{C} \mathrm{m}^{-2} \mathrm{~d}^{-1}\right)$ values were higher than those previously observed in this high nutrients low chlorophyll area (Signorini et al., 1999), probably due to the vertical input of dissolved iron from subsurface waters (Blain et al., 2008). From October to March, wind-driven coastal upwelling fertilizes the surface waters off Chile leading to one of the most productive areas in the world ocean (Carr, 2002). In the same way, $Z_{10 \%}$ in the UVB, UVA, and visible spectral domains showed great variability with the highest values recorded in GYR ( $21 \mathrm{~m}$ at $305 \mathrm{~nm}$ to $113 \mathrm{~m}$ at $443 \mathrm{~nm}$ ) and the lowest values measured in UPW ( $3 \mathrm{~m}$ at $305 \mathrm{~nm}$ to $18 \mathrm{~m}$ at $565 \mathrm{~nm}$ ) (Table 2). The values reported in GYR suggest that this area likely contains the clearest oceanic waters of the world ocean (Morel et al., 2007; Tedetti et al., 2007). 


\subsection{Concentration levels of TDNS and FDNS}

Concentrations of TDNS (free and combined) in depth profiles ranged from $58 \mathrm{nM}$ (EGY, $250 \mathrm{~m}$ ) to $890 \mathrm{nM}$ (MAR, $30 \mathrm{~m}$ ), the second maximum value reached being observed at EGY (492 $\mathrm{nM}$ at $80 \mathrm{~m}$ ). Two general trends can be observed in a first approach:

1. the depth profile patterns followed those of TChl- $a$ for MAR and EGY, although a significant correlation between TChl- $a$ and TDNS was observed only at EGY $(r=0.95, p<0.01)$. This probably reflects the high contribution from autotrophic organisms from cellular release processes (Fig. 2). There were no other significant correlations (considering sites individually or all together) neither with TChl- $a$ (as source), nor with DOC (as bulk stock), nor with leucine incorporation rates (as measure of DOC uptake processes).

2. TDNS concentrations at the highly eutrophic site of UPW (149-328 nM) were not as much elevated as someone may expect for an eutrophic regime. Indeed, the maximum value in UPW was lower than that observed in the highly oligotrophic GYR (79-389 nM). This feature was kind of surprising because TChl- $a$, and I-PP values were one order of magnitude higher in UPW than in GYR (Fig. 2; Table 1).

Similar TDNS concentrations in the upper $500 \mathrm{~m}$ (180$800 \mathrm{nM}$ ) have been already observed in Equatorial Pacific (Skoog and Benner, 1997), Northeastern Pacific and Sargasso Sea (Borch and Kirchman, 1997), Central Arctic (Rich et al., 1997), Ross Sea (Kirchman et al., 2001), as well as in ultrafiltrated DOM samples (20-661 nM) collected from Equatorial Pacific and Arctic Oceans (Skoog and Benner, 1997; Amon and Benner, 2003). It is worth to note that higher sugar concentrations (1000-4000 nM) above the thermocline were reported only for coastal samples (e.g. inshore the Oregon coast; Borch and Kirchman, 1997, Arctic estuarine samples; Amon and Benner, 2003). Our TDNS concentration results are not comparable to those obtained by colorimetric techniques [3-methyl-2-benzothiazolinone hydrazone (MBTH) or 2,4,6-tripyridyl-s-triazine (TPTZ)] because these techniques include in their analysis a much broader spectrum of sugars including methylsugars, aminosugars, uronic acids etc. These compounds were outside the analytical window of the HPAEC-PAD technique under our current analytical conditions (Borch and Kirchman, 1997; Skoog and Benner, 1997; Panagiotopoulos and Sempéré, 2005).

Although our sugar measurements were made only in the upper layers and we did not obtain data from the entire water column, we expect that sugar concentrations will decrease with depth. Reported literature data below the thermocline ranged from 90 to $450 \mathrm{nM}$ for Northeastern Pacific, Equatorial Pacific and Sargasso Sea (Borch and Kirchman, 1997; Skoog and Benner, 1997), and from 31-68 nM for deep Arctic water samples (Amon and Benner, 2003). These results
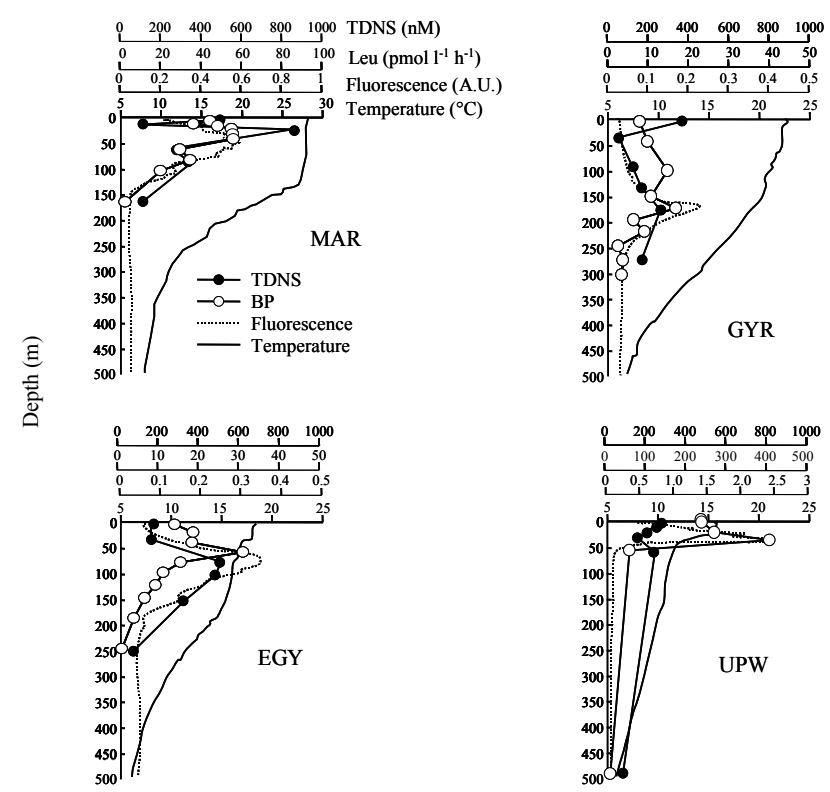

Fig. 2. Depth profiles of total dissolved neutral sugars (TDNS in $\mathrm{nM})$, leucine incorporation rates (LEU, pmol $\mathrm{l}^{-1} \mathrm{~h}^{-1}$ ), chlorophyll fluorescence (arbitrary unit), and temperature $\left({ }^{\circ} \mathrm{C}\right)$ at the four stations in the South East Pacific.

are in good agreement with our deepest TDNS concentrations $(110 \mathrm{nM}$ at $160 \mathrm{~m}$ for MAR, $185 \mathrm{nM}$ at $270 \mathrm{~m}$ for GYR, $58 \mathrm{nM}$ at $250 \mathrm{~m}$ for EGY and $149 \mathrm{nM}$ at $500 \mathrm{~m}$ for UPW).

FDNS concentrations were within the detection limit of the PAD $(5-10 \mathrm{nM})$ in most of the sites and ranged from undetectable to $35 \mathrm{nM}$ (MAR, $30 \mathrm{~m}$ ). Our results are much lower than those found in the Equatorial Pacific (20-110 nM; Rich et al., 1996), and Central Arctic (31-68 nM; Rich et al., 1997) but similar to that reported in Gulf of Mexico (3-7 nM; Skoog et al., 1999), and Ross Sea (0-14 nM; Kirchman et al., 2001). FDNS comprised a small fraction of TDNS in all stations and generally were $<5 \%$ of the TDNS.

\subsection{TDNS and FDNS yields}

TDNS yields were calculated by dividing TDNS-C by dissolved organic carbon (DOC) (Raimbault et al., 2008) and as such are presented as a percentage of DOC (TDNSC $\times \mathrm{DOC}^{-1} \%$ ). TDNS yields ranged from 0.4 (GYR, $40 \mathrm{~m}$ ) to $6.7 \%$ (MAR, $30 \mathrm{~m}$ ). At MAR higher TDNS yields were measured $(3.3 \% \pm 2.2 \%$; significantly higher than the other sites, $p<0.05)$, which probably reflects a terrestrial influence. Indeed, Signorini et al. (1999) reported the importance of the Marquesas Island mass effect in the stimulation of PP up to $1000 \mathrm{~km}$ downstream from the island. Our results are in good agreement with previous values reported from the Equatorial Pacific (1-7\%, Rich et al., 1996; 2-6\%, Skoog and Benner, 1997), Ross Sea (1-11\%, Kirchman et al., 2001), and Central Arctic (2-20\%, Rich et al., 1997). 
MAR

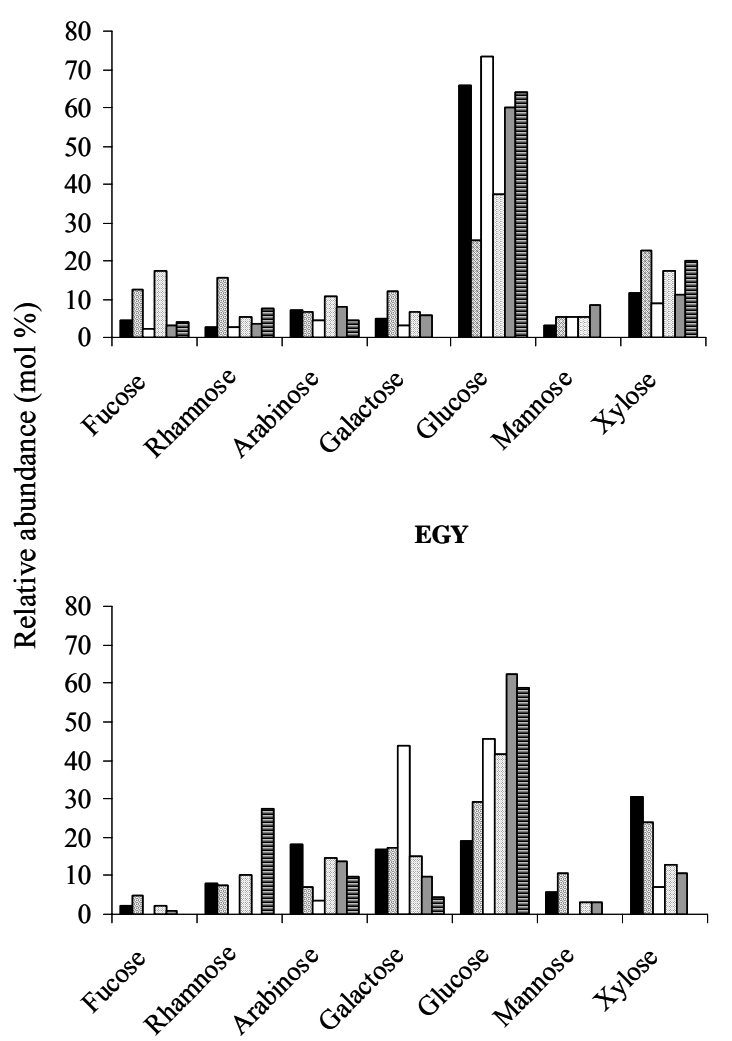

GYR

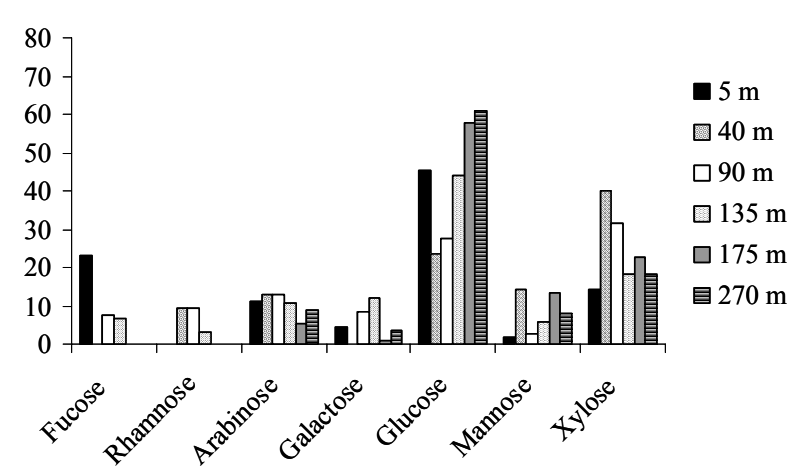

UPW

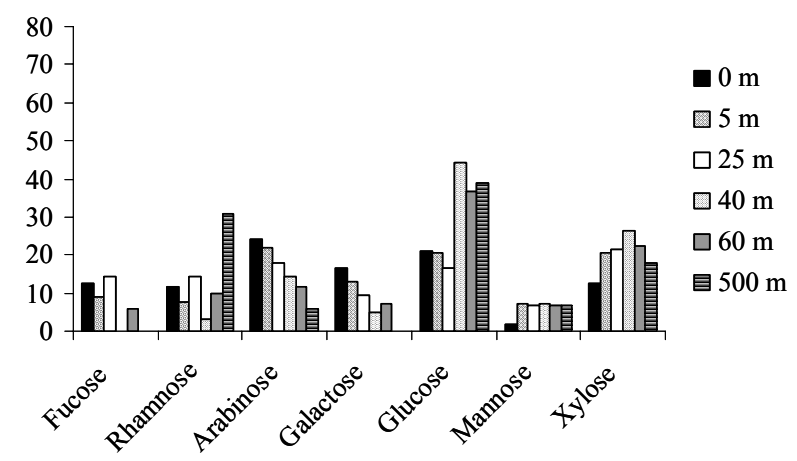

Fig. 3. Relative abundance of total dissolved neutral sugars (TDNS in mol \%) at the four stations in the South East Pacific.

\subsection{Molecular composition of TDNS and FDNS}

Three major sugar classes were detected in South East Pacific samples including the aldohexoses (glucose, galactose and mannose), deoxysugars (fucose and rhamnose), and aldopentoses (arabinose and xylose). Concentrations of ribose (aldopentose) are not reported here because they were very low and often not detected (Fig. 3). Aldohexoses were in most of the sites the most abundant compound class (30$727 \mathrm{nM}$ ) followed by aldopentoses (27-131 nM), and deoxysugars $(<10-91 \mathrm{nM})$. Glucose was very often the most abundant $(15-77 \%$ of the TDNS) followed by xylose $(7-40 \%)$, arabinose (4-24\%), and galactose (3-44\%). Mannose, fucose and rhamnose were less abundant accounting $<10 \%$ of the total sugar pool. Note that xylose was predominant at 40 and $90 \mathrm{~m}$ at GYR and at $5 \mathrm{~m}$ water depth of the EGY stations, whereas arabinose was predominant at UPW in the first 0-25 m (Fig. 3).

Our results indicated that glucose was clearly the most abundant sugar at greater depths $(>40 \mathrm{~m})$, and that its relative abundance increase with depth in GYR and in EGY (Fig. 3). The dominance of glucose within the TDNS pool was reported from several oceanic regions including the Equatorial Pacific (0-4000 m, 21-61\%; Skoog and Benner, 1997), Sar- gasso Sea (surface, 35\%; Borch and Kirchman, 1997), Central Arctic (0-40 m, 39\%; Rich et al., 1997), and Antarctic (0-60 m, 35-37\%; Kirchman et al., 2001). Glucose was also the only detectable sugar within the FDNS pool with concentrations ranging from 2 to $10 \mathrm{nM}$ in most of the sites (see above). The $100 \%$ abundance of glucose in the FDNS pool for our South East Pacific samples is in agreement to that reported in Gulf of Mexico (Skoog et al., 1999), and Ross Sea (Kirchman et al., 2001). Other studies carried out in the Equatorial Pacific and central Arctic indicated that glucose $(47-79 \%)$, fructose (15-16\%), and arabinose (5-15\%) were present in the FDNS pool (Rich et al., 1996; Rich et al., 1997).

\subsection{Sugar stocks in relation with biological activity}

TDNS stocks integrated to the DCM ranged from 612 (UPW) to $2190 \mathrm{mg} \mathrm{C} \mathrm{m}^{-2}$ (MAR). Intermediate values were found at GYR and EGY (2154 and $1439 \mathrm{mg} \mathrm{C} \mathrm{m}^{-2}$ ).

Because DCMs depths were very different among sites direct comparison of integrated TDNS stocks is not possible. However, these results indicate that sugars are, relatively to BP, more abundant in the euphotic layer in the SPG (GYR) and on its border (EGY) than in zones of higher PP (MAR and UPW; Fig. 4). Because sugars are by-products of PP 
Table 3. Doses (surface irradiances integrated over time) received by the DOM-solutions during the photodegradation experiments in the UVB $(305 \mathrm{~nm})$, UVA $(325,340,380 \mathrm{~nm})$ and visible $(412,443,490,565 \mathrm{~nm})$ spectral domains at the four stations in the South East Pacific.

\begin{tabular}{llllllllll}
\hline \multicolumn{10}{c}{ Dose $\left(\mathrm{kJ} \mathrm{m}^{-2}\right)$} \\
\hline Site & Sky & $305 \mathrm{~nm}$ & $325 \mathrm{~nm}$ & $340 \mathrm{~nm}$ & $380 \mathrm{~nm}$ & $412 \mathrm{~nm}$ & $443 \mathrm{~nm}$ & $490 \mathrm{~nm}$ & $565 \mathrm{~nm}$ \\
MAR & sunny & 2.2 & 11.9 & 16.2 & 22.9 & 36.8 & 41.6 & 47.0 & 43.9 \\
GYR & cloudy & 1.4 & 7.7 & 10.5 & 14.5 & 22.9 & 25.1 & 27.5 & 25.2 \\
EGY & cloudy & 1.3 & 7.4 & 10.1 & 13.8 & 21.8 & 23.9 & 26.2 & 23.8 \\
UPW & sunny & 2.5 & 13.5 & 18.4 & 25.9 & 41.3 & 46.6 & 52.7 & 49.0 \\
\hline
\end{tabular}

and are essentially consumed by bacteria, our results indicate large variability across the transect between dissolved sugars production by PP and derived processes and its utilization by bacteria.

Excess-dissolved sugars relative to BP in oligotrophic to hyperoligotrophic (GYR, EGY) waters might be explained by the accumulation of recalcitrant sugars due to rapid diagenetic processes governed by microorganisms and/or to nutrient deficiency which results in low bacterial activity. Our results clearly showed low TDNS/BP ratios in highly productive area (UPW, MAR; Fig. 4) suggesting that TDNS are rapidly exhausted by bacterial consumption. On the other hand, in the less productive areas (GYR and EGY), TDNS are relatively abundant with respect to BP (Fig. 4), and therefore accumulate in the surface layer. These results are consistent with Raimbault et al. (2008) observations indicating high concentrations of DOC as well as elevated DOM C/N ratios in the euphotic zone (GYR: 16-18; EGY: 13-18), significantly higher $(p<0.01)$ compared to MAR $(12-15)$. Such features might be related to a malfunctioning of the microbial loop with severely nutrient limited heterotrophic bacteria (Thingstad et al., 1997). Indeed, Van Wambeke et al. (2007) using enrichment experiments, reported clear BP limitation by nitrogen at GYR. Because of low horizontal advection as well as low seasonal convective mixing at GYR (Raimbault et al., 2008), BP nitrogen limitation is likely to be predominant all over the year (Van Wambeke et al., 2007), leading to an accumulation of sugar-rich DOC in surface waters.

\subsection{Bacterial responses to DOM photodegradation}

Solar doses (surface irradiances integrated over time) received by the DOM-solutions during the photodegradation experiments are presented in Table 3. Doses were higher at MAR and UPW (sunny days), ranging from $\sim 2.2$ $(305 \mathrm{~nm})$ to $52.7 \mathrm{~kJ} \mathrm{~m}^{-2}(490 \mathrm{~nm})$, than at GYR and EGY (cloudy days), ranging from $\sim 1.3(305 \mathrm{~nm})$ to $27.5 \mathrm{~kJ} \mathrm{~m}^{-2}$ (490 nm; Table 3). A complete assessment of solar UV doses is provided in Van Wambeke et al. (2008b). DOMphotodegradation and -biodegradation experiments indicated different effects of solar radiation on the DOM bioavailability to heterotrophic bacteria (Fig. 5). At MAR and EGY, surface DOM photodegradation led to a significant stimulation

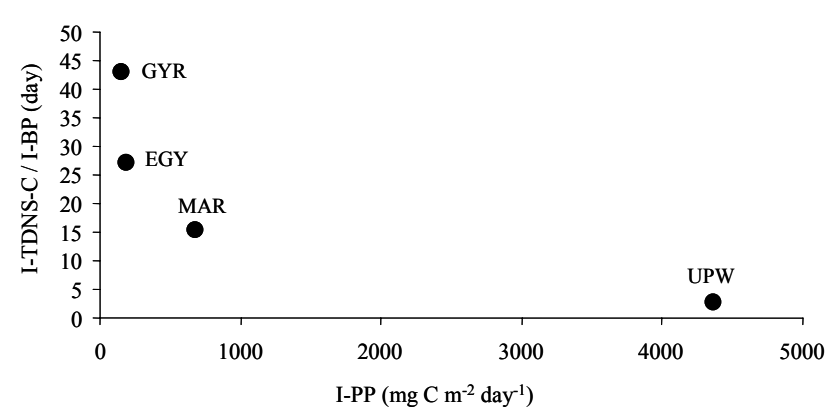

Fig. 4. Relationship between I-TDNS-C/I-BP ratios [total dissolved neutral sugars expressed in carbon units integrated down to DCM (I-TDNS-C in $\mathrm{mg} \mathrm{C} \mathrm{m}^{-2}$ ) and bacterial production integrated down to DCM (I-BP in $\left.\mathrm{mg} \mathrm{C} \mathrm{m}^{-2} \mathrm{day}^{-1}\right)$ ] and primary production integrated down to DCM (I-PP in $\mathrm{m} \mathrm{C} \mathrm{C}^{-2} \mathrm{day}^{-1}$ ) at the four stations in the South East Pacific.

of leucine incorporation rates by 150 and $133 \%$, respectively (FS compared to Dark, $p<0.05$ for both comparisons). However, the photodegradation of DOM collected deeper $(180 \mathrm{~m}$ at MAR and $80 \mathrm{~m}$ at EGY) increased significantly leucine incorporation rates only at EGY (by $80 \%, p<0.05$; Fig. 5 ). Van Wambeke et al. (2007) found that heterotrophic bacteria were not bottom-up controlled at MAR, whereas they were limited by labile DOC (e.g. glucose) at EGY. We did not detect any significant photochemical production of FDNS during the photodegradation experiments. Therefore, the stimulation of leucine incorporation rates after the DOM irradiation may be explained by the photochemical production of (other) bioavailable low molecular weight organic compounds such as aldehydes or organic acids that have been shown to be the major DOM-derived photoproducts (Kieber et al., 1990; Moran and Zepp, 1997; Mopper and Kieber, 2002). At GYR, surface DOM photodegradation did not significantly change leucine incorporation rates $(p>0.05)$. This was maybe due to the very low content in chromophoric (photoreactive) DOM in surface waters of the SPG (Morel et al., 2007) that prevents any photochemical processes to occur. On the other hand, Van Wambeke et al. (2007) observed that at GYR, BP was limited by nitrogen and not labile DOC. Thus, even though some organic photoproducts might have been released from DOM irradiation, they could not in turn substantially increase BP. The photodegradation of DOM collected in the 


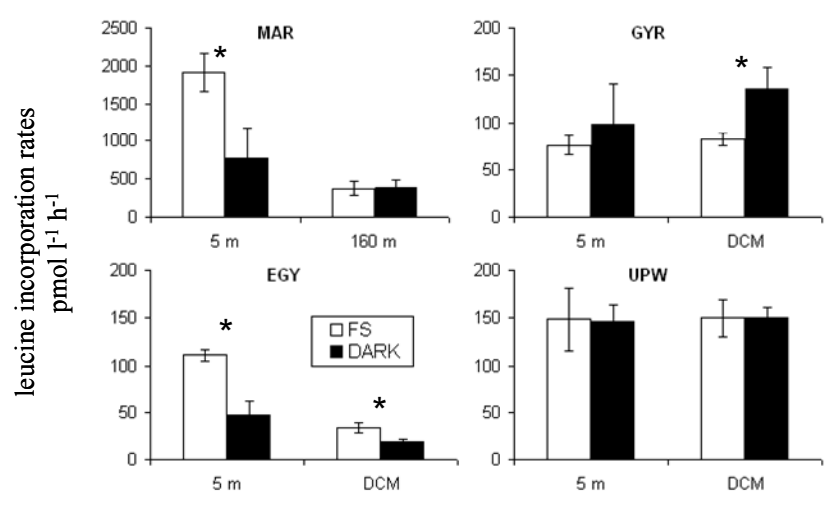

Fig. 5. Leucine incorporation rates (pmol leu $l^{-1} h^{-1}$ ) after $48 \mathrm{~h}$ (MAR) or $72 \mathrm{~h}$ (GYR, EGY, UPW) incubation of irradiated DOMsolution $(0.2-\mu \mathrm{m}$ filtered seawater $)$ with a bacterial non-irradiated inoculum $(0.8-\mu \mathrm{m}$ filtered seawater, inoculum/DOM-solution final ratio $1 / 6$,) at the four stations in the South East Pacific. Samples were collected at two depths, i.e. $5 \mathrm{~m}$ and DCM, except in MAR (5 and $160 \mathrm{~m})$. DOM-solutions were irradiated under natural solar radiation $(\sim 8 \mathrm{~h}$ around solar noon) in full sun (FS, white bars) or kept in the dark (Dark, black bars). Error bars represent standard deviations for pooled measurements of duplicate subsample for each duplicate experiment.

* Significant differences (Mann Whitney test, $p<0.05$ ) between full sun and dark treatments.

DCM of GYR significantly inhibited BP by $40 \%(p<0.05$; Fig. 5). This decrease could be related to the photochemical production of biorefractory compounds (Kieber et al., 1997). DOM irradiation in UPW resulted no significant difference in BP for both surface and DCM samples ( $p>0.05$ for both comparisons; Fig. 5). This absence of response may be attributed to the high amount of labile carbon initially present in the upwelling system, i.e. heterotrophic bacteria were not limited in carbon before DOM photodegradation. These different bacterial responses to DOM photodegradation reflect differences in the nature and chemical composition of DOM before irradiation (Moran and Covert, 2003).

\section{Summary and conclusion}

This study showed a diversity of TDNS amounts in the South East Pacific waters. At all sites investigated, TDNS make up only 0.4 to $6.7 \%$ of DOC. Although TDNS variations were very large along vertical profiles, maximum values were reached at stations of intermediate trophic status like MAR and EGY, but not the more eutrophic (UPW). In this highly productive area of the Chile upwelling where both PP and BP were particularly elevated, high turnover of labile DOM was reflected by low TDNS/IBP ratios. There was no noticeable effect of solar radiation on DOM bacterial assimilation in such environments probably because of the high water mixing. In contrast, TDNS concentrations relative to bacterial production were higher in the center of the SPG (GYR) and to a lesser extent in the eastern border of the SPG (EGY). We found that at GYR, TDNS were accumulated with respect to the low primary and heterotrophic bacterial productions, and reinforce the idea of limitation of bacterial growth by nitrogen (Van Wambeke et al., 2007). Such feature is consistent with the DOC accumulation (Raimbault et al., 2008) and likely considering the relatively old character of the surface DOM revealed by its elevated $\mathrm{C} / \mathrm{N}$ ratios (Raimbault et al., 2008). The DOM which accumulates in the surface waters of GYR, does not seem to be photoreactive as indicated by the photo (bio)degradation experiments. Indeed, it has been hypothesized that DOM in this area was continuously photobleached in the surface waters due to the high level of stratification and to high surface UV irradiances (Morel et al., 2007). Other stations, EGY and MAR, showed moderate TDNS concentrations and turnover regarding bacterial and primary productions.

Acknowledgements. We are grateful to the captain and crew of the RV "L'Atalante" for excellent service during the BIOSOPE cruise. We acknowledge H. Claustre and A. Sciandra as chief scientists of the cruise, as well as C. Bournot, D. Taillez and D. Merien for CTD operations. We thank J. Raas and P. Raimbault for providing TChl$a$ and DOC data, respectively. We also acknowledge T. Moutin and S. Duhamel for providing primary production data and the two referees for improving the MS. K. Mopper gave a substantial help to our group for improving the quality of the desalination procedure. This research was funded by CNRS-PROOF projects (BIOSOPE and UVECO), and the Region of Provence Alpes Côte d'Azur.

Edited by: A. Boetius

\section{References}

Aluwihare, L. I., Repeta, D. J., and Chen, R. F.: A major biopolymeric component to dissolved organic carbon in seawater, Nature, 387, 166-167, 1997.

Amon, R. M. W. and Benner, R.: Combined neutral sugar as indicators of the diagenetic state of dissolved organic matter in the Arctic Ocean, Deep-Sea Res. Pt. I, 50, 151-169, 2003.

Blain, S., Bonnet, S., and Guieu, C.: Dissolved iron distribution in the tropical and sub tropical South Eastern Pacific, Biogeosciences, 5, 269-280, 2008, http://www.biogeosciences.net/5/269/2008/.

Benner, R. and Kaiser, K.: Abundance of amino sugars and peptidoglycan in marine particulate and dissolved organic matter, Limnol. Oceanogr., 48, 118-128, 2003.

Benner, R., Pakulski, J. D., McCarthy, M., Hedges, J. I., and Hatcher, P. G.: Bulk chemical characteristics of dissolved organic matter in the ocean, Science, 255, 1562-1564, 1992.

Benner, R.: Chemical composition and reactivity, in: Biogeochemistry of Marine Dissolved Organic Matter, edited by: Hansell, D. and Carlson, C., Academic Press, New York, USA, 59-90, 2002.

Borch, N. H. and Kirchman, D. L.: Concentration and composition of dissolved combined neutral sugars (polysaccharides) in seawater determined by HPLC-PAD, Mar. Chem., 57, 85-95, 1997. 
Burney, C. M. and Sieburth, J. M.: Dissolved carbohydrates in seawater - II: A spectrometric procedure for total carbohydrate analysis and polysaccharide estimation, Mar. Chem., 5, 15-28, 1977.

Carr, M. E.: Estimation of potential productivity in Eastern Boundary currents using remote sensing, Deep-Sea Res. Pt. II, 49, 5980, 2002.

Claustre, H. and Maritorena, S.: The many shades of ocean blue, Science, 302, 1514-1515, 2003.

Claustre, H., Sciandra, A., and Vaulot, D.: Introduction to the special section bio-optical and biogeochemical conditions in the South East Pacific in late 2004: the BIOSOPE program, Biogeosciences, 5, 679-691, 2008, http://www.biogeosciences.net/5/679/2008/.

Kieber, R. J., Hydro, L. H, and Seaton, P. J.: Photooxydation of triglycerides and fatty acids in seawater: implication toward the formation of marine humic substances, Limnol. Oceanogr., 42, 1454-1462, 1997.

Kieber, R. J., Zhou, X., and Mopper, K.: Formation of carbonyl compounds from UV-induced photodegradation of humic substances in natural waters: Fate of riverine carbon in the sea, Limnol. Oceanogr., 35, 1503-1515, 1990.

Kirchman, D. L., Meon, B., Ducklow, H. W., Carlson, C. A., Hansell, D. A., and Steward, G.: Glucose fluxes and concentrations of dissolved combined sugars (polysaccharides) in the Ross Sea and Polar Front Zone, Antarctica, Deep-Sea Res. Pt. II, 48, 4179-4197, 2001.

Mopper, K. and Kieber, D. J.: Photochemistry and the cycling of carbon, sulphur, nitrogen and phosphorus, in: Biogeochemistry of marine dissolved organic matter, edited by: Hansell, D. A. and Carlson, C. A., Academic Press, San Diego, CA, USA, 455-507, 2002.

Mopper, K., Schultz, C., Chevolot, L., Germain, C., Revuelta, R., and Dawson, R.: Determination of sugars in unconcentrated seawater and other natural waters by liquid chromatography, Environ. Sci. Technol., 26, 133-137, 1992.

Moran, M. A. and Covert, J. S.: Photochemically mediated linkages between dissolved organic matter and bacterioplankton, in: Aquatic ecosystems: interactivity of dissolved organic matter, edited by: Findlay, S. E. G. and Sinsabaugh, R. L., Academic Press, San Diego, CA, USA, 243-262, 2003.

Moran, M. A. and Zepp, R. G.: Role of photoreactions in the formation of biologically labile compounds from dissolved organic matter, Limnol. Oceanogr., 42, 1307-1316, 1997.

Morel, A., Gentili, B., Claustre, H., Babin, M., Bricaud, A., Ras, J., and Tieche F.: Optical properties of the "clearest" natural waters, Limnol. Oceanogr., 52, 217-229, 2007.

Painter, T. J.: Algal polysaccharides, in: Polysaccharides, edited by: Aspinall, G. O., Academic, New York, USA, 195-285, 1983.

Pakulski, J. and Benner, R.: Abundance and distribution of carbohydrates in the ocean, Limnol. Oceanogr., 39, 930-940, 1994.

Panagiotopoulos, C. and Sempéré, R.: Molecular distribution of carbohydrates in large marine particles, Mar. Chem., 95, 31-49, 2005.

Panagiotopoulos, C., Sempéré, R., Lafont, R., and Kerhervé, P.: Effects of temperature in the determination of monosaccharides by using an anion-exchange column, J. Chromatogr., 920, 13-22, 2001.
Parsons, T. R., Takahashi, M., and Hargrave, B.: Biological oceanographic processes, Pergamon, Oxford, UK, 1984.

Raimbault, P., Garcia, N., and Cerutti, F.: Distribution of inorganic and organic nutrients in the South Pacific Ocean - evidence for long-term accumulation of organic matter in nitrogen-depleted waters, Biogeosciences, 5, 281-298, 2008, http://www.biogeosciences.net/5/281/2008/.

Ras, J., Claustre, H., and Uitz, J.: Spatial variability of phytoplankton pigment distributions in the Subtropical South Pacific Ocean: comparison between in situ and predicted data, Biogeosciences, 5, 353-369, 2008, http://www.biogeosciences.net/5/353/2008/.

Rich, J. H., Ducklow, H. W., and Kirchman, D. L.: Concentrations and uptake of neutral monosaccharides along $140^{\circ} \mathrm{W}$ in the equatorial Pacific: contribution of glucose to heterothrophic bacterial activity and the DOM flux, Limnol. Oceanogr., 41, 595604, 1996.

Rich, J. H., Gosselin, M., Sherr, E., Sherr, B., and Kirchman, D. L.: High bacterial production, uptake and concentrations of dissolved organic matter in the central Arctic Ocean, Deep-Sea Res. Pt. II, 44, 1645-1663, 1997.

Signorini, S. R., McClain, C. R., and Dandonneau, Y.: Mixing and phytoplankton bloom in the wake of the Marquesas Islands, Geophys. Res. Lett., 26, 3121-3124, 1999.

Skoog, A. and Benner, R.: Aldoses in various size fractions of marine organic matter: Implications for carbon cycling, Limnol. Oceanogr., 42, 1803-1813, 1997.

Skoog, A., Biddanda, B., and Benner, R.: Bacterial utilization of dissolved glucose in the upper water column of the Gulf of Mexico, Limnol. Oceanogr., 44, 1625-1633, 1999.

Smith, D. C. and Azam, F.: A simple, economical method for measuring bacterial protein synthesis rates in sea water using $3 \mathrm{H}-$ Leucine, Mar. Microb. Food Webs, 6, 107-114, 1992.

Stouthamer, A. H.: Energetic aspects of the growth of microorganisms, Symp. Soc. Gen. Microbiol., 27, 285-315, 1977.

Tedetti, M., Sempéré, R., Vasilkov, A., Charrière, B., Nérini, D., Miller, W. L., Kawamura, K., and Raimbault, P.: High penetration of ultraviolet radiation in the south east Pacific waters, Geophys. Res. Lett., 34, L12610, doi:10.1029/2007GL029823, 2007.

Thingstad, T. F., Hagstrom, A., and Rassoulzadegan, F.: Accumulation of degradable DOC in surface waters: Is it caused by a malfunctioning microbial loop?, Limnol. Oceanogr., 42, 398-404, 1997.

Van Wambeke, F., Bonnet, S., Moutin, T., Raimbault, P., Alarcón, G., and Guieu, C.: Factors limiting heterotrophic bacterial production in the southern Pacific Ocean, Biogeosciences, 5, 833845, 2008, http://www.biogeosciences.net/5/833/2008/.

Van Wambeke, F., Obernosterer, I., Moutin, T., Duhamel, S., Ulloa, O., and Claustre, H.: Heterotrophic bacterial production in the South East Pacific: longitudinal trends and coupling with primary production, Biogeosciences, 5, 1-13, 2008a, http://www.biogeosciences.net/5/1/2008/.

Van Wambeke, F., Tedetti, M., Duhamel, S., and Sempéré, R.: Diel variability of heterotrophic bacterial production and UV doses in the South East Pacific, Biogeosciences Discuss., 5, 435-462, $2008 b$, http://www.biogeosciences-discuss.net/5/435/2008/. 